\title{
Pedology: history and contemporaneity
}

\author{
Natalia Sukhova ${ }^{1, *}$, Lera Yurkina $^{2}$, Vladimir Leonov ${ }^{1}$, Sergey Greshnikov ${ }^{1}$ \\ ${ }^{1}$ Moscow State Regional University, 10A, Radio str, 105005, Moscow, Russia \\ ${ }^{2}$ Moscow State Linguistic University, 38, Ostozhenka str, 119034, Moscow, Russia
}

\begin{abstract}
This article is a study devoted to the scientific direction that existed in the 30-40-s in the system of general pedagogy - pedology. The article examines the origins of interest in the scientific and comprehensive study of childhood, the history of the emergence and development of pedology abroad and in Russia. In this study, the emergence of pedology in Russia is interpreted by the authors as a response to the growing interest of social and humanitarian knowledge in the personality of the child and the spread of the ideas of humanism that came to Russia from the West. However, due to the prevailing social, political conditions, as well as objective reasons that are analyzed in the work, pedology was abolished and the interdisciplinary study of childhood was suspended for a long time. The presented material also provides an analytical overview of the main directions of the formation of pedology as an academic subject for pedagogical educational institutions in the period of the 30 -s -40 -s. The sources used were educational programs and textbooks on pedology, works of pedologists of the 30-s - 40-s, articles from the journal "Pedology", documents of the People's Commissariat of Education and archival materials. In addition, the article attempts to highlight the range of pedological problems relevant to the modern educational system.
\end{abstract}

\section{Introduction}

The problem of humanizing society in general and education in particular, is viewed as a priority in the public consciousness of the 21-st century. Being the main trend in the development of education around the world, it is considered as the leading principle of reforming the educational system in modern Russia. The need to humanize Russian education became especially acute in the early 90 -s.

This was determined by a number of reasons both of an objective nature (dehumanization of society as a whole, economic instability, stratification and social insecurity of a significant part of the population, interethnic and international conflicts, loss of values and a deep moral crisis), and the shortcomings of the existing educational system (the prevalence of classroom studies over independent work of students; lack or insufficient attention to the development of the creative potential of the student's personality; weak information support of the educational process; decrease in the quality of education, falling students' interest in learning, deterioration of the moral atmosphere within the walls of educational institutions, etc.).

\footnotetext{
${ }^{*}$ Corresponding author: angela-1309.m@yandex.ru
} 
Humanization of education presupposes, first of all, its maximum individualization and differentiation. The solution to this problem allows us to place the child at the center of the educational process, to see his/her unique personality, to concentrate on his/her individuality, to build the educational process taking into account his needs and abilities. As a result, the main task of the harmonious development of the personality will be not just the formation of various spheres of its activity (mental, moral, etc.), but the development of the potential inherent in each child in accordance with his individuality.

Pedology was one of the directions in the development of world and domestic sociopedagogical thought, which in theory and practice dealt with the solution of these educational problems in the 20-40-s. Exactly its theoretical and methodological heritage reflected, developing over the centuries, the tendency of an integrated approach to the study of the child, his development and formation as a person. Simultaneously with the emergence of pedology as a field of scientific knowledge, it began to form as an academic subject, and this was especially relevant for the system of pedagogical education in Russia, which was looking for fundamentally new approaches to the content of training future teachers. Under the conditions of post-revolutionary Russia, pedology as an academic subject fulfilled its specific tasks: it armed future teachers with objective knowledge about the child, the influence of various factors and forces on his development. In this regard, the consideration of pedology as an academic subject is of particular relevance.

\section{Materials and methods}

The theoretical and methodological basis of the study was:

- philosophical and pedagogical concepts of humanistic education (P.P. Blonsky, N.I. Pirogov, K.D. Ushinsky);

- the concept of personality-oriented education (N.A. Alekseev, D.A. Belukhin, E.V. Bondarevskaya, V.V. Serikov, I.S. Yakimanskaya);

- theoretical provisions on the essence, structure and development of pedology (E.A. Arkin, M.Ya. Basov, P.P. Blonsky, L.S. Vygotsky, A.B. Zalkind, A.P. Nechaev, S. Hall);

- modern studies of the actualization of the experience of pedology (V.F. Baranov, N.P.Sechenov, A.V. Svetlichnaya, L.V. Pokhilko, S.N. Tsenyuga, F.A. Fradkin).

Research methods used in the process of writing the work:

Theoretical analysis of philosophical, psychological, pedagogical, pedological literature on the research topic; historical and genetic analysis; comparison; classification; systematization; generalization of theoretical positions and facts, forecasting.

\section{Results}

The meteoric rise of pedology as a branch of scientific knowledge dates back to the beginning of the 20-th century. Initially, pedology emerged as a direction of pedagogical science, which appeared in the United States at the turn of the XIX-XX and became very popular in Western Europe.

This phenomenon was dictated by the fact that by the end of the 19-th and the beginning of the 20-th century, a significant number of specialists in various scientific fields (psychology, pedagogy, sociology, physiology, etc.) showed significant interest in the problem of child development and, in this regard, significant factual material was accumulated, which required a theoretical foundation. Pedology became a science that saw its main task in forming a holistic idea of the development of a child at different age stages, based on the data of various directions. 
After the emergence in the United States, it was soon enough to talk about the pedological movement in Europe, headed by such famous scientists as E. Meuman, J. Sulli, V. Stern, K. Bühler and others.

It should be noted, however, that at the beginning of the 20-th century Russia lagged significantly behind Europe and the United States in the development of pedology. This was dictated by the low level of development and conservatism of education and, accordingly, the actual impossibility to apply the ideas of pedology in practice. According to L.S. Vygotsky's pedology in Russia represented a "living corpse" [11, 56].

The situation begins to change after the October Revolution and the Civil War, when in a dilapidated, half-starved country there is a need for economic recovery, and, consequently, the elimination of illiteracy, which reached colossal proportions - 100 million people (as of 1916). The Soviet government, realizing the importance of the tasks facing it, urgently adopts a program for the elimination of illiteracy, schools for children and adults are being opened everywhere. Already at this stage, attempts are being made to apply pedological tests to determine the level of development of students. In other words, the norms and methods of a pedological nature begin to be used in the process of creating a "new socialist man". Here is what one of the founders of pedology in Soviet Russia, the famous teacher and psychologist A.B. Zalkind, wrote about this:

"The main practical question put forward by the new social system is the question of changes in the mass man in the process of socialist influence on him. This question is pedological because it is in childhood (and the sphere of pedology is childhood!), In the era of development, growth of a person, the environment turns out to be the most powerful, decisive factor that creates the main attitudes of development that determines all the main prospects for the further existence of a person "[10,6].

The preconditions for the emergence of pedology in Russia were also discoveries in the field of physiology, medicine, the emergence of experimental pedagogy and psychology. In addition, in an effort to overcome one of the significant shortcomings of the old school - the isolation of learning from life and to solve the main task set for the new school by the socialist society under construction and to educate an active builder of socialism, Soviet pedagogical teachers focused their attention on systematizing knowledge about the methods of training child to this life.

In this regard, the idea of overcoming the separation of school from life, and pedagogy from the child, has become extremely relevant. In this situation, the lack of integrated knowledge about the child was especially acute. In addition, scientists sought to obtain a comprehensive knowledge about the development of a child, which is necessary for education and training, and this complex problem could be solved only within the framework of pedological science.

One of the famous Soviet scientists who actively promoted pedology was L.S. Vygotsky. He wrote that pedology was intended to become the methodological basis of its constituent scientific disciplines, without eliminating their independent existence $[9,56]$.

During the same period of time, a network of pedological institutions was developing in Soviet Russia. Great teachers and psychologists of the 1920-s are fond of pedology: P.P. Blonsky, M.Ya. Basov, A.B. Zalkind and others. Considerable literature is being created, new pedological centers appear, congresses and conferences are held.

Analysis of the pedagogical literature of that period allows us to determine the main directions of development of pedological science, formulated by its authors:

- value attitude towards a child and childhood as a unique period of a person's life;

- a holistic approach to studying the age-related development of a child;

- creation of a comprehensive typology of children at different age stages of development; 
- development of methods for studying the age-related development of the child, allowing to obtain integrated knowledge about the age-related development of the child;

- the creation of a psychological and pedagogical service in the education system [18].

Progressive Soviet pedologists, promoting the ideas of the new school, wrote that the school should become a place not only for learning, but for the life of the child, the school environment should create conditions conducive to the rational organization of this life in order to develop a "moral value, autonomous personality" And further, in the new conditions, the school must put the child at the forefront, or rather his activities, which will stimulate his self-development, and the role of the teacher will be to give the child knowledge and organize his activities in such a way that it contributes to his selfdevelopment [8].

In this regard, by the end of the 1920 -s, a pedological service began to operate in schools and other educational institutions, the main task of which is "the rationalization of pedagogical work and school life on the basis of pedology."

Particularly valuable in the work of school pedologists was that they worked closely with teachers, parents and doctors. Each of the specialists had their own functional responsibilities: a medical worker monitored the physical condition of both children and teachers, and the pedologist monitored and corrected the general mental development of students.

The work of pedologists during this period of time was very diverse: they worked a lot and productively with difficult adolescents, actively carried out psychological and pedological counseling, worked with parents and the public. In addition, all the achievements in the field of both theoretical and practical pedology were published in the journal "Pedology", which was in press from 1928 to 1932.

An important area of activity of pedologists during the 1920-s was research work, which was carried out in all divisions of the education system: schools, nurseries, kindergartens, FAS, in addition, a whole network of experimental stations and schools was created under the People's Commissariat for Education of the RSFSR.

In the same period of time, pedological universities and research institutes appeared, staffed by representatives of various sciences. Their task was to study the characteristics of the development of children in the period from birth to adolescence. In addition to research activities in the field of pedology, these institutions were engaged in the training of new cadres of pedagogical teachers. The content of this training included knowledge in pedagogy, psychology, physiology, child psychiatry, neuropathology, anthropology, sociology, and theoretical studies were combined with everyday practical work.

It should be noted, however, that if we bear in mind the theoretical development, then the pedologists of this time did not have a unanimity of opinion on many fundamental issues. The most acute of them were associated with the construction of pedology, more precisely, the principle of selection of knowledge and the formation of a system of science. In these issues there was a lot of unclear, on them there were sharp disputes between representatives of different approaches, tk. their views diverged significantly. Everything depended on what area of knowledge about the child the theorist of pedology had previously studied, what experience he had in practical work with children, etc.

Most objectively, the system of pedology, its problems and approaches to their solution, all its achievements and miscalculations can be understood by getting acquainted with the construction of the training course.

If we compare the system of constructing psychology and pedology as educational subjects, we can see that they largely duplicate the same educational material. However, the course in psychology reflected mainly knowledge of general issues. It did not contain material revealing the psychology of childhood, adolescence, adolescence, as well as the psychological characteristics of the organization of the educational process. But all these 
questions were reflected in the pedology course. They were revealed using data from biology, anatomy and physiology, and medicine.

The content of the course of pedagogy of 30-40-s the issues that were given in the content of the pedology course were also not covered. It follows from this that pedology as an academic subject fulfilled its specific tasks: it armed future teachers with knowledge about the child, his development, the influence of various factors and forces on the development process.

The heated debates that were waged between psychologists and pedologists, on the one hand, and teachers, on the other, concerned most of all questions of theory, the originality of the subject of pedology, and its methodological foundations. Acquaintance with the scientific and educational literature on pedology convincingly confirms that over the years of its existence both in our country and abroad, pedology has not been able to truly solve these issues. Nevertheless, the analysis of the pedology curriculum system shows that it contains and systematizes such knowledge about the child, which undoubtedly could help the teacher to better understand him, professionally solve the issues of the child's upbringing and development.

One of the famous pedagogical scientists of the 1930-s, the founder of pedology in Soviet Russia was P.P. Blonsky. It was in the 30 -s that he intensively engaged in the development of pedology as a science and the improvement of its teaching in pedagogical educational institutions. Explaining the motives that prompted him to take up pedology, he wrote the following: "Since 1924 I consider myself not a teacher, but a pedologist. When I very keenly felt that I began to write, that my pedagogical articles were becoming more and more empty and primitive, I decided to apply as a living source, to pedology. For me it was quite natural, since I came to pedagogy from psychology and now I was retreating, as it were, to my previous positions. When I surrendered to pedology, many reproached me for leaving pedagogy. But the previous winer's pedological congress showed me how timely my departure was. Literally every month more and more teachers turn to pedology, and I am only happy about it. The study of childhood, no doubt, will give teachers a lot of new strength and a lot of new content. Paradoxically, I left pedagogy, so as not to completely lose pedagogy" $[6,44]$.

P.P. Blonsky wrote three textbooks on pedology in a fairly short period of time, and in 1936, which became fatal for pedological science in Soviet Russia, a third edition was prepared, which remained unpublished for obvious reasons.

Of particular interest is the one developed by P.P. Blonsky the problem of the relationship between pedological and chronological age in the development of a child. The characteristics of age-related development are deeply and consistently given, starting from intrauterine childhood and ending with newborn and infancy.

For the first time in the psychological and pedagogical literature there is a detailed description of the development of a child in the second year of life, given under the general heading "The little one". The material on these periods ends with the appendix of tests. Experts should judge their quality, but the very desire of the author to provide a tool for measuring the course of development of children at this age seems to be progressive not only for that time, but also for our days. It is at this age, as modern scientific research and practice show, that a lag and an advance in human development are outlined.

Deep enough P.P. Blonsky reveals the development process of a preschooler, junior schoolchild and adolescent. In the characteristics of these age periods, transitional stages are distinguished, general and peculiar features of the child's development are revealed, a detailed description of the development of the psyche is given, the problems of the relationship of children with the people around them and society are revealed in a meaningful and deep way $[1,56]$. 
Attention is also drawn to the author's desire to give a differentiated description of an underdeveloped and very developed student, a disorganizer (the term of that time - N.S.) and a lazy child.

In the second edition of the textbook, in comparison with the curriculum, the issues of pedology at school are developed. The special work of P.P. Blonsky "Pedology in a mainstream school".

The questions indicated in this section of the program seem to be very relevant. Take, for example, the problem of recruiting classes, which has always been especially acute, but has not been solved. Pedology didn't shrug it off and tried to solve it.

In textbooks and other literature on pedology, one can also see the emergence of a new approach to the study of pedagogical disciplines - instead of scholastic memorization of the material, tasks are formulated, the fulfillment of which involves the use of diagnostic methods used in pedology $[5,173]$.

In addition, in the training courses of pedagogical universities, the problem of the practical use of theoretical developments in the field of pedology has significantly advanced: in a fairly short period of time, pedologists have developed and brought to practical use a variety of measurement techniques, and also created and functioned an extensive service of pedological offices in large cities of the country, in which was carried out to follow the children who caused difficulties in teaching and upbringing.

It should be noted, however, that if theoretical work was carried out by highly educated people who have achieved high results in the development of various branches of the human sciences: psychology, physiology, pedagogy and child psychiatry, then nothing of the kind could be said about mass practice. Many practitioners had the enthusiasm and desire to help the teacher in solving his problems, but lacked knowledge. Using the methods of examining large masses of children, pedologists believed that only they, better than psychologists and teachers, know the students. This led to a violation of mutual understanding between pedologists, on the one hand, and psychologists and educators, on the other.

Unfortunately, experiments with pedology carried out in our country in the 1920-s and 1930-s did not bring the expected results.

To teach pedology and provide staff for numerous offices, qualified personnel were needed. There were not enough of them, it was necessary to train both teachers and practical pedologists for short courses. This could not but affect the quality of their work. In addition, the process of forming pedology as a field of scientific knowledge has not been completed, and its data have already begun to be used in practice.

During the 20-30-s in the USSR, testing according to the Binet-Simon system began to be actively used. Their founding author A. Binet in 1904, on the instructions of the French government, developed tests aimed at intelligence diagnosing - a technique that helped separate children who are capable of learning, but lazy, from children suffering from birth defects.

During testing under this system, children from families belonging to classes hostile from the point of view of the Soviet government showed the highest results. The results of students with a worker-peasant origin were significantly lower. This situation greatly annoyed the leadership of the People's Commissariat for Education of the RSFSR and opponents of pedology, since, from their point of view, it had a political connotation.

It should also be noted that in the 30 -s the idea of examining a child in order to develop the pedagogical features of his upbringing has lost its original meaning [2,17]. The child and the children's collective began to be studied from the standpoint of ideological attitudes. As in the case of other social sciences, pedology is increasingly acquiring a class character. 
The use of pedological techniques in teaching adults was not successful; the preparation of the teachers, which conducted the testing, as noted above, left much to be desired. Science was not prepared for the comprehensive study of the child, the theory and methods were not sufficiently developed, and there was a shortage of qualified scientific personnel. The idea of synthesis of scientific disciplines at the level of the studied subject began to be replaced by the mechanical connection of these disciplines.

In addition, if the theoretical work was carried out by highly educated people who have achieved high results in the development of various branches of human sciences: psychology, physiology, pedagogy and child psychiatry, then nothing of the kind could be said about mass practice. Many practitioners had the enthusiasm and desire to help the teacher in solving his problems, but lacked knowledge. Using the methods of examining large masses of children, pedologists believed that only they, better than psychologists and teachers, know the students. This led to a violation of mutual understanding between pedologists, on the one hand, and psychologists and educators, on the other.

In 1936, after the publication of the decree of the Central Committee of the the Central Committee of the All-Union Communist Party of the Bolsheviks "On pedological perversions in the system of the People's Commissariat for Education" [17], pedology was abolished. This resolution put an end to the development of pedology in the USSR for a long time. Pedology was declared a pseudoscience, and its teaching in Soviet pedagogical institutes is prohibited. All publications in one way or another related to pedology were withdrawn from circulation and the overwhelming majority destroyed, and most of the pedagogical scientists were repressed. All those who studied the child and in one way or another considered themselves to be pedologists, regardless of their specific specialization, were left without work: psychologist, doctor, teacher, etc. All pedological institutes and laboratories were closed.

The prohibition of pedology undoubtedly had a negative impact on the development of psychological and pedagogical sciences, namely:

- pedagogical practice has ceased to be guided to the required degree by taking into account the individual and age characteristics of the child;

- the educational process was reoriented towards the "average student", and gifted children and children with disabilities were left without due attention;

- research in the field of differentiated education and training has ceased;

- schools for children with impairments or delays in psychophysical development were closed;

- education was reoriented towards a knowledge-based approach, the personality of the child was left without proper attention;

- decreased interest in empirical research in pedagogy, in tests;

- the gap between different sciences studying the age patterns of the child has increased;

- in the process of knowledge control, subjectivity in assessments began to prevail;

- research in the field of diagnostics and experimental pedagogy has stopped [18].

In the decree of the decree of the Central Committee of the All-Union Communist Party of Bolsheviks "On pedological perversions in the system of the People's Commissariat for Education", as arguments for its failure, its weakest aspects were cited, which the specialists in pedology themselves considered insufficiently developed. In a negative light, the developments of pedologists - practitioners were presented and on this basis science itself was condemned, methods of objective study of the child and the educational process, which were not actually pedological, were buried. Behind the individual weaknesses of pedology as a theory, shortcomings in practice, that valuable that was achieved not only in pedology, but also in psychology and pedagogy adjacent to it, was thrown overboard. And a lot has been done. A variety of measurement techniques were developed and brought to practical use. An extensive service of pedological offices was created and functioned in the 
cities of the country. To teach pedology and provide staff for numerous offices, qualified personnel were needed. There were not enough of them, they had to train both teachers and practical pedologists for short-term courses - all this could not but affect the quality of their work.

Criticizing these shortcomings, representatives of pedology urged not to lose sight of the achievements of this emerging branch of pedagogical knowledge. This is how T.K. Chuguev in his article "On Projector Attacks on Pedology": "You can't just go too far and talk about the absolute sterility of pedology, not see absolutely any achievements in the pedological area. Did not pedology help and does not help primary school teachers to better teach children, taking into account A clear proof of this help can be the fact that the book by P.P. Blonsky "Pedology in a mass school" has withstood 8 editions in several years. Has pedology not helped and does not help the teacher in analyzing the question of difficult children, about their typology, about the fight against difficulties and about the adaptation of the educational process to their characteristics?" [20, 46].

The communists-Leninists N.K. Krupskaya and A.S. Bubnov saw and noticed the contradictions and shortcomings in the development of pedology. In a speech at an allRussian meeting of pedagogical schools, N.K. Krupskaya noted: "Pedology is a new science, a number of issues are not resolved ..., many pedologists have moved away from practical issues, which is especially detrimental for pedology as a science" $[20,18]$. While criticizing the state of affairs in the field of pedology, she at the same time emphasized: "I cannot imagine a good modern Soviet teacher who does not know pedology. Every teacher must master pedology. Without this he will not be able to lead a child, influence him ..." $[12,18]$. In the same vein, the question of pedology was raised by A.S. Bubnov. Rightly noting the shortcomings in her theoretical attitudes and in the practice of her work, he did not consider it possible to "blame" the shortcomings of the education system on pedologists. "And if they (pedologists - approx. N.S), - he noted, - work unsatisfactorily, then we must not only make demands on them, but also practically help them in finding the right line and achieving the proper practical results" $[7,65]$.

To notice the shortcomings, to help eliminate them, to involve theorists in practical work - this is a truly scientific approach to the management of education and the development of science.

Summing up, it should be noted that according to statistics, Russia entered the 20-th century as a country with total illiteracy. In the second half of the thirties, virtually every citizen of the Soviet state was literate. What is the role of pedology in this we can only guess. And yet, a radical change in the policy of eliminating illiteracy fell on the first decade and a half of Soviet rule. At that time, pedology in the RSFSR and later in the USSR. She developed and taught in pedagogical universities to future teachers, which means that her role in this is indisputable.

Only in the 1960-s were timid attempts made to rehabilitate certain norms of pedology. The pioneer in this matter was the psychologist A.V. Petrovsky. In his research, the scientist focuses on the fact that many pedological methods and norms are positively used in other sciences of physiology, developmental psychology, medicine, and others [16].

Abroad, all the achievements of pedology, including those that were available in our country, enriched pedagogy and psychology, continued to improve. From the pedological service, our colleagues abroad approached the creation of a psychological service. They adopted everything that was productive in the organization of pedological offices in the 30 $\mathrm{s}$ and 40 -s. This allowed them to achieve great success in organizing education. However, with regard to the current state of pedology abroad, in the modern world this direction appears not so much as a science, but as a type of professional activity, in terms of child psychology and, to a lesser extent, psychology of well-being $[8,87]$. 
At present, Russian society is at a turning point in its development, and a reassessment of values is taking place. Introduced new Federal State Educational Standards, Professional Teacher Standard. In recent years, researchers and practitioners have often turned to the ideas and experience of pedagogy, psychology, and pedology in the 1920-s and 1930-s.

So, for example, the Fundamental principles of the activity of pedologists, which have not lost their significance at the present time, were:

- refusal to study the child "in parts", obtaining a synthesis of knowledge of various anthropological sciences about child development;

- study of the child as a developing being;

- research of the child in the environment in which he lives and develops;

- the transition from studying a child to changing him, finding a practical application of the results obtained [18].

Outstanding psychologist, pedologist L.S. Vygotsky fully shared the point of view of his contemporaries, pedologists that the main task of the school pedologist-teacher was the rationalization of pedagogical work and school life on the basis of pedology, that the school should be a place not only for learning, but for the child's life, should create a rational organization of this life in order to development of a "morally valuable, autonomous personality" $[9,58]$.

It is quite obvious that the school psychologist is faced with similar problems in the modern school: "The psychologist introduces into the activities of the teaching staff the basic psychological idea of the possibility of harmonious development of the personality of each student, promotes its implementation in practical work" $[14,14]$.

Further, the following can be named as the main directions of practical activity of pedologists in the 1920-s:

- organization and rationalization of school life;

- work related to pedological examination of students

- cultural and educational activities [18].

It is obvious that the psychological service in a modern general education school, among others, solves these problems.

In addition, it should be noted that the emergence of Russian defectology as a field of scientific knowledge miraculously coincided with the period of rapid development of pedology in Soviet Russia. It is quite obvious that Soviet defectology developed under the influence of pedology, the main task of which was a comprehensive study of the child, i.e. physiological, psychological and social aspects of this development.

Nevertheless, it should be noted that both the theoretical and practical experience of pedologists in the 1930-s and 1940-s requires a critical rethinking. This is indicated by the authors who analyze pedology. So, for example, M.V. Telegin, in his work "Apologetics of Traditional Education", saw "parallelism" between modern, as he calls them, "innovators" and pedologists of the 1930-s and 1940-s. In particular, he writes that this is evidenced by the endless "reforms" of the modern secondary school and the total enthusiasm for tests and the Unified State Exam "turn the educational process into cramming scattered particulars, details, facts and minor facts. Tests can be successfully passed without understanding the essence, without having holistic conceptual thinking in one or another subject area ... Test and USE, to paraphrase L.S. Vygotsky, everywhere and everywhere they go ahead of the educational process, lead it along "[19].

The author further notes that, ultimately, most children have "mosaic, patchwork, dotted consciousness. A monstrous conglomerate of scraps, fragments, pieces ... There is a lot of information - little sense. Default information. It is not cooked, not taken, not understood. Landmarks and criteria were destroyed " [19].

The author draws the readers' attention to another significant drawback in the work of the modern Russian school, which, in his opinion, is a "practical heritage of pedology" - 
this is a complex structure of curricula that does not allow the school to provide students with systematic and deep scientific knowledge. In particular, he writes: "The systematic study of individual subjects has been destroyed. The entire volume of knowledge outlined in the "integrated approach", the logics of science, academic discipline ... is replaced by the "logics" of the creator of the "complex" ...

The psychological and pedagogical "digging" under the traditional school ends in the same way - a monstrous degradation of education "[19].

It should be noted, however, that many productive ideas of pedology in the 30-40-s are successfully implemented by developmental psychology and pedagogy, defectology, they formed the basis of psychological and pedagogical diagnostics, the experience of pedologists is widely used in the work of the psychological and pedagogical service in the education system. It is also unconditional that integrative training of students of pedagogical educational institutions in the field of the age-related development of the child is absolutely necessary.

\section{Discussion}

Pedology as a direction of pedagogical science originated in the United States at the turn of the XIX-th - XX-th centuries and became very popular in Western Europe. Such famous scientists as E. Meuman, D. Sulli, W. Stern, K. Bühler and others became the head of the pedological movement in Europe. Each of them made his own significant contribution to the development of pedological science.

So J. Sulli, being the founder of the development of child and educational psychology in England, formulated the main provisions of the associationistic approach to child development. J. Sulli proceeded from the premise that a child is born only with the prerequisites of the basic mental processes that are formed during life. These prerequisites are three elements that make up the basis of the main constituents of the psyche - mind, feelings and will. During life, there is an association of individual elements (sensations, movements), which are combined (integrated) into a holistic image of an object, into a representation or concept. His works "Essays on the Psychology of Childhood" (1895) and "Educational Psychology" (1894-1915) were of great importance for the development of practical child psychology [17].

J. Sulli's ideas were further developed in the writings of Maria Montessori, who used his approaches to child development and developed a system of exercises aimed at the intellectual development of preschool children.

A German psychologist made a significant contribution to the development of pedology E. Meuman. In his writings, he paid great attention to the applied aspects of child psychology and pedology, arguing that their main task is to create a methodological basis for teaching children.

Synthesizing the achievements of psychologists with the problems of the development of children's abilities (aesthetic ideas, the development of memory, patterns of rapid and lasting memorization), E. Meuman was one of the first to put forward the principle of selfdevelopment of a child and substantiate the importance of his activity in the educational process.

In his writings, he wrote that education and upbringing should be based not so much on knowledge of the general laws of the child's mental development, as on an understanding of the characteristics of the psyche of a particular individual. The merit of E. Meuman is also the fact that he developed his periodization of the cognitive development of the child and was one of the first to put forward the problem of interaction between teacher and students and the reaction of students to different styles of communication in full [15]. 
A significant contribution to the psychology of child development was made by the famous German psychologists K. Bühler and W. Stern, the latter studying the spiritual development of personality, developed the theory of personalism, the foundations of which he outlined in his fundamental work "Personality and Thing". (1906-1924).

Nevertheless, the American psychologist and educator Griven Stanley Hall is rightfully considered the founder of pedology. According to Stanley Hall, pedology is a combination of psychology, physiology, medicine and hygiene [15, 9-13].

In pre-revolutionary Russia, pedological ideas were developed in the brilliant works of Russian teachers K.D. Ushinsky (1857), N.N. Pirogov (1810), P.F. Lesgaft (1900), P.K. Kaptereva (1890), N.N. Lange (1882).

So N.I. Pirogov was one of the first to raise the question of the need for a comprehensive, primarily psychological study of a person, knowledge of the patterns of his development, identification of conditions and factors that determine the formation of the child's mental sphere.

A significant contribution to the development of such problems as the psychological nature of education, its limits and capabilities, the relationship between education and development, the combination of external educational influences and the process of selfeducation, was made by the great Russian teacher K.D. Ushinsky. He wrote: "The art of education is based on the data of anthropological sciences, on complex knowledge about a person who lives in a family, in society, among the people, among humanity and alone with his conscience."

Among the pedologists of the Soviet period, it should be noted such as Vygotsky L.S., Zalkind A.B., P.P. Blonsky, L.S.Vygotsky considered pedology as a complex science of the full age development of a child, which is a combination of anatomical, physiological, psychological, biological and sociological approaches to its development. He considered the child's socialization the main problem of pedology, and the object was the integral process of child development. L.S.Vygotsky wrote that the development of a normal and an abnormal child is subject to the same laws and goes through the same stages, but these stages in a child with developmental disabilities are extended in time, and the presence of a defect gives originality to each variant of this development.

"The main practical question put forward by the new social system," asserted the official leader of the pedological movement in the country, A.B. Zalkind, "is the question of changes in the mass man in the process of socialist influence on him. This question is pedological because it is in childhood (and the sphere of pedology is childhood!), In the era of development, growth of a person, the environment turns out to be the most powerful, decisive factor that creates the main attitudes of development, determining all the main prospects for the further existence of a person " $[10,15]$.

The 1936 resolution "On pedological perversions in the system of the People's Commissariat for Education" permanently deleted pedology from the Soviet education system, and only in December 1988 at the All-Union Congress of Public Education Workers in the main report it was proposed "to revise ...the criticism of pedology, at a new level, to intensify the study of abilities children and their consideration in teaching practice". It should be noted that the list of problems associated with the study of pedology by modern authors is very small. They consider the following questions in their dissertation research:

Pedological research of a child in the domestic pedagogical heritage of the first third of the 20-th century (Doctor of Pedagogical Sciences Nikolai Petrovich Senchenkov, 2006);

Pedology as a science of child development: Genesis, state, prospects (candidate of pedagogical sciences Svetlichnaya, Angela Vladimirovna, 2006);

The axiological foundations of P.P. Blonsky (candidate of pedagogical sciences Pokhilko Lyudmila Vasilievna 2003); 
Formation and development of the theory and practice of pedological work in the public education of the Yenisei region in the second half of the 19-th - first third of the 20-th centuries. (Doctor of Pedagogical Sciences Tsenyuga, Sergey Nikolaevich 2010).

Experimental pedagogy in Russia in the works of domestic teachers of the late 19-th early 20-th centuries. (Candidate of Pedagogical Sciences Mereshkova Zita Ibragimovna 2006).

At the same time, it should be noted that such an important issue as the influence of pedology on the content of training future teachers in pedagogical universities in Russia in the 1920-s and 1940-s has not been reflected in existing studies. It was important for the authors of the proposed study to identify and characterize the main directions of pedological training of teachers in higher pedagogical educational institutions in the period of the $30 \mathrm{~s}-40 \mathrm{~s}$ and outline ways to implement its achievements in modern pedagogical theory and practice.

\section{Conclusions}

The studies of numerous modern authors are devoted to a critical analysis of pedology that existed in the USSR during the 1920s and 1940s.

Many of them blame the pedology of the 1920s for its enthusiasm for calculations and mechanization of the processes of teaching and upbringing and their complete biologization, however, the listed shortcomings of pedology were overcome by the beginning of the 30s. During this period of time, pedology "grew" as a science, many of its representatives, who were engaged exclusively in theoretical research, began to actively introduce their developments into practice, and this, of course, had a positive effect on the quality of the work of practical pedologists. At the same time, in pedology, there were significant contradictions between the level of development of theoretical questions and the practice of mass examinations of students, there were shortcomings in the training of pedologists-practitioners, which caused serious criticism from many teachers. Moreover, until the end of its existence, pedology as a science did not have its own subject of research, and it largely coincided with the subject of psychology.

More productive, from our point of view, is the analysis of the problems associated with determining the place of pedology in the educational process, its organization. The analysis of the structure of the subject made it possible to draw conclusions that:

- pedology focused the teacher on in-depth study of the child, armed him with objective methods of this study;

- the content of her course supplemented, and did not duplicate, as it was claimed, knowledge in the field of pedagogy and psychology;

- pedology as an academic subject gradually moved away from the verbal way of considering educational material, formulating tasks for students, giving methods of their implementation;

- she strove to ensure a differentiated approach to the study of a real child with all its contradictions and difficulties.

After the decree of July 4, 1936, scholastic, bookish methods of studying psychology and pedagogy became dominant. Slowly, with great difficulties, theory and practice came to the conclusion about the need for deep study of students. Only in 1988

The State Committee for Public Education of the USSR put on a practical plane the issue of creating a psychological service in schools. Experiments in this regard were carried out by psychologists a little earlier. But this work was mainly carried out taking into account foreign experience. The valuable experience of pedological offices' activities turned out to be unused. These are the fruits of incompetent interference in the development of science. 


\section{References}

1. M.Y. Basov, Pedologiya 5 - 6, 3 - 28 (1931)

2. V.F. Baranov, Zhurnal «Voprosy psikhologii» 4, 100-112 (1991)

3. A. Bine, T. Simoni, Metody izmereniya umstvennoy odaronnosti (M., 1923)

4. P.P. Blonskiy, Izbrannyye pedologicheskiye i pedagogicheskiye sochineniya (M., 1979)

5. P.P. Blonskiy, Pedologiya: Ucheb. dlya vys. ped. uchebnykh zavedeniy (M., 1934)

6. P.P. Blonskiy, Izbrannyye pedagogicheskiye proizvedeniya (M., 1961)

7. A.S. Bubnov, Kom. Prosveshcheniye 2, 58-73 (1991)

8. L.S. Vygotskiy, Zhurnal «Pedologiya» 1, 78-100 (1931)

9. L.S. Vygotskiy, Pedologiya M. 3, 56 (1931)

10. A.B. Zalkind, Pedologiya v SSSR (M., 1929)

11. A.B. Zalkind, Pedologiya (1928)

12. N.K. Krupskaya, Ped. Obrazovaniye, 17-20 (1934)

13. K voprosu o «Profile pedologa», Zhurnal «Pedologiya» 2, 91- 93 (1931)

14. Narodnoye obrazovaniye v SSSR: Sb. dokumentov (M., 1974)

15. A.P. Nechayev, Osnovatel' pedologii Stenli Kholl i yego nauchnaya deyatel'nost'. Pedagogika i psikhologiya (SPb, 1904)

16. A.V. Petrovskiy, Zapret na kompleksnoye issledovaniye detstva (Repressirovannaya nauka, M., 1991)

17. Postanovleniye TSK VKP(b) ot 4 iyulya 1936 g. "O pedologicheskikh izvrashcheniyakh v sisteme narkomprosov», Narodnoye obrazovaniye v SSSR: Sb. dokumentov (M., 1974)

18. Programmy pedagogicheskikh institutov, Pedagogika (M., 1933)

19. Rabochaya kniga shkol'nogo psikhologa (M., Prosveshcheniye, 1991)

20. A.A. Romanov, Istoriko-pedagogicheskiy zhurnal 4, 122-138

21. N.Ye. Rumyantsev, Pedologiya (Nauka o detyakh) (SPb, 1910)

22. Dzh. Selli, Ocherki po psikhologii detstva (M., URSS, 2019)

23. A.V. Svetlichnaya, Pedologiya kak nauka o razvitii rebenka: genezis, sostoyaniye, perspektivy: Avtoref. diss. kand. ped. nauk (Yekaterinburg, 2006)

24. M.V. Telegin, Apologetika traditsionnogo obucheniya (Moskva: De Novo, 2011)

25. K.D. Ushinskiy, Chelovek kak predmet vospitaniya. Opyt pedagogicheskoy antropologii (L., APN, 1948)

26. G.K. Chuguyev, Ped. Obrazovaniye 6, 44 - 52

27. D. Shul'ts, S. Shul'ts, Istoriya sovremennoy psikhologii (SPb., 2002) 